\title{
CALIBRATION COMMENTARY
}

\author{
S P E Blockley ${ }^{1}$ R A Housley ${ }^{2}$ \\ Department of Geography, Royal Holloway, University of London, Egham, Surrey TW20 0EX, United Kingdom.
}

Radiocarbon is by far and away the most widely used dating tool in the Late Quaternary. Hundreds of key papers rely on the method to provide absolute and relative chronological information on important topics, including the late evolution of our own species (e.g. Higham et al. 2006a) and the timing and nature of abrupt climatic changes during the last glaciation (Lowe et al. 2001). Calibration of ${ }^{14} \mathrm{C}$ determinations is an essential part of the dating process, and the implications of calibration can lead to significant differences in the interpretation of important processes (Blockley et al. 2006). Any development that enhances the accuracy, precision, or time coverage of the calibration curves is therefore to be welcomed. Since the early 1980s, there has been periodic publication of carefully vetted data in the form of internationally recognized consensus calibration curves that have allowed ${ }^{14} \mathrm{C}$ users to convert their raw ${ }^{14} \mathrm{C}$ determinations into calendar ages (Klein et al. 1982; Stuiver and Reimer 1986, 1993; Stuiver et al. 1998; Reimer et al. 2004). In the beginning, the basis on which this was done was easy to understand, ${ }^{14} \mathrm{C}$ measurements were made on tree rings and the absolute calendar age came from counting annual growth rings. Although not without its complexities, the terrestrial tree-ring approach remains the most certain method and is at the heart of calibration process in the period 0-12.4 cal kyr. However, for periods beyond the limit of the tree-ring sequences the situation was significantly more problematic, and at times, even controversial.

In 2004, the IntCal working group provided marine data, with site-specific regional reservoir corrections for the period 12.4-26 cal kyr; however, they made no recommendation for calibration/comparison beyond this point (Reimer et al. 2004). Users wishing to correct age determinations beyond $26 \mathrm{cal}$ kyr faced a dilemma - confronted as they were by a myriad of conflicting calibration data sets from differing environmental sources the errors on which few had sufficient knowledge to comprehend-many decided to stay with uncalibrated ${ }^{14} \mathrm{C}$ determinations. The problem became particularly acute when users using uncorrected ages attempted to compare their ${ }^{14} \mathrm{C}$ chronologies with absolutely dated climate data (e.g. Greenland ice-core records) or non- ${ }^{14} \mathrm{C}$ ages (e.g. OSL, ${ }^{40} \mathrm{Ar} /$ ${ }^{39} \mathrm{Ar}$, etc.), for this resulted in a series of "apples and oranges" comparisons where ${ }^{14} \mathrm{C}$ "years" became mistakenly equated with calendar years, leading to misleading science.

Calibration became more contentious in 2005 when R G Fairbanks and his coauthors published their 2 papers claiming to have produced a superior ${ }^{14} \mathrm{C}$ calibration curve extending to $50 \mathrm{cal} \mathrm{kyr} \mathrm{BP}$ (Chiu et al. 2005; Fairbanks et al. 2005). Highly critical of the methodology of the IntCal working group, the authors successfully undermined any remaining (externally perceived) cohesion within the ${ }^{14} \mathrm{C}$ producers' community. Their calibration curve is easily available to any user who wishes to use it (http://www.radiocarbon.ldeo.columbia.edu/research/radiocarbon.htm).

In a sense, the genie was out of the bottle long before the intervention of Fairbanks et al. For many years, CalPal (e.g. Danzeglocke et al. 2007) has provided the means to combine ${ }^{14} \mathrm{C}$ data sets for the purposes of calibration. Using this computer calibration program, any user with a modicum of knowledge can select which ${ }^{14} \mathrm{C}$ record they wish to use as a means to "calibrate"/compare their age data. The key to getting something of value from this is in understanding the limits and weaknesses

\footnotetext{
${ }^{1}$ Email: Simon.Blockley@ rhul.ac.uk.

${ }^{2}$ Email: rupert.housley@rhul.ac.uk.

(C) 2009 by the Arizona Board of Regents on behalf of the University of Arizona Celebrating 50 Years of Radiocarbon

RADIOCARBON, Vol 51, Nr 1, 2009, p 287-290
} 
of the different data sets. It is all very well to have access to a high-resolution climate proxy record from, for example, Greenland, but how applicable is it to an age data set from the Indian Ocean monsoon region, or a central Asian loess sequence? While one might applaud a freeing up of the "ownership of time" (cf. van Andel 1998), with freedom comes responsibility and users who wish to compare their data with different ${ }^{14} \mathrm{C}$ calibration data sets have to become better educated in the strengths and weaknesses of the different proxies. It is clear from the calibration papers in Radiocarbon 50th anniversary special issue that the science may have moved on, but have all the users of ${ }^{14} \mathrm{C}$ data? There is an essential case to be made for getting this message over to the user community.

Recent developments in tuning proposed calibration curves to different calendar records have resulted in the calibration process moving forwards. The recent retuning of the Cariaco record has resulted in a new Cariaco curve (Hughen et al. 2006) that now agrees broadly with the Fairbanks curve and it seems that a new consensus curve may soon be with us. Calibration is a vital part of the ${ }^{14} \mathrm{C}$ dating process; however, it is not the magic answer to everything. What are the implications of this for the archaeological community (and by this we mean Paleolithic archaeologists since only these need worry about calibration past the endpoint of the tree-ring sequences)? The problem of age underestimation as one gets close to the $40,000-50,000{ }^{14} \mathrm{C}$ yr upper age limit is not addressed by age correction, and this will remain a significant issue. The chemical pretreatment issues, for example, that are connected with the extraction of carbonaceous protein in antler, bone, and ivory and the purification of charcoal are particularly relevant to the ability to accurately date archaeological samples beyond 25-30 kyr BP. Improvements connected with ultrafiltration and other, as yet unforeseen, developments are likely to be just as important as which calibration data set to use.

Users of ${ }^{14} \mathrm{C}$ dates, though themselves driven primarily by interests in other processes, need to be actively embedded in ${ }^{14} \mathrm{C}$ science; from a detailed understanding of the finer points of ${ }^{14} \mathrm{C}$ pretreatment (Higham et al. 2006b), through to the intricacies of calibration. Taking the question of the timing of the Middle to Upper Paleolithic in Europe, the apparent pattern is that some regions of Europe have an Upper Paleolithic transition broadly in the range of 32,0000-35,000 yr ago, while there is also evidence for very late Neanderthal survival in southern Iberia (e.g. Finlayson et al. 2008). Additionally, there have been several attempts to test for the relationship between climate change and evolutionary transitions at this time. There are, however, a number of uncertainties to be considered, both in the timing of the onset of the Upper Paleolithic across most of Europe and the possibilities for very late Neanderthal survival. These uncertainties concern both ${ }^{14} \mathrm{C}$ "quality assurance" and ${ }^{14} \mathrm{C}$ calibration. These problems are exemplified by data relating to the widespread Campanian Ignimbrite tephra, located in numerous archaeological and environmental records from Italy to Russia (Pyle et al. 2006). This tephra is very well dated by multiple ${ }^{40} \mathrm{Ar} /{ }^{39} \mathrm{Ar}$ isochron ages to $39,282 \pm 110$ (De Vivo et al. 2001). The ${ }^{14} \mathrm{C}$ ages for this isochron, however, from archaeological sites where it has been located close to the Middle to Upper Paleolithic transition, range from 32,000-35,000 ${ }^{14} \mathrm{C}$ yr. In this case, a single event can be smeared over many thousands of ${ }^{14} \mathrm{C}$ yr. Moreover, none of the available ${ }^{14} \mathrm{C}$ calibration data resolve this and can only produce a reliable calendar age for this tephra, if the majority of archaeological dates are rejected (Blockley et al. 2007). Thus, we do not know if the dates are the problem or the curve, although the former seems the more likely. This is not meant to sound negative, science moves on and ${ }^{14} \mathrm{C}$ dating is becoming more secure all the time, even towards the limits of the technique. The challenge for users is to engage properly with the science.

One of the significant scientific developments that has enabled users to actively engage with the science is the growth in the application of Bayesian methods to ${ }^{14} \mathrm{C}$ problems. Pioneered initially by Caitlin Buck and colleagues (Buck et al. 1991), with later proliferation through the availability of useful software such as OxCal (Bronk Ramsey 2001, 2008) and BCal (Buck et al. 1999), the appli- 
cation of Bayesian techniques to integrate ${ }^{14} \mathrm{C}$ and other information has become an influential tool. The method, which allows the use of prior knowledge, such as the relative depths of different stratigraphical units, in the calculation of model ages, is particularly useful for ${ }^{14} \mathrm{C}$-based problems, as we are often dating samples from a known stratigraphical or cultural context. Initially, the use of Bayesian methods was restricted to archaeological problems, where the use of phasing information has made Bayesian methods an ideal tool, giving archaeologists the ability to discuss timescales at the generational level (e.g. Bayliss et al. 2007).

The uses of Bayesian methods have now moved out into wider areas of archaeology and on into Quaternary science. One key area has been at the interface between archaeology and Quaternary paleoclimate reconstruction. Here, the aim has been to understand the timing of demographic changes evident in the archaeological record of the late Pleistocene and their relationship to the abrupt climate events also evident in numerous archives from that time (Housley et al. 1997; Blockley et al. 2006). The appropriate statistical methods proved crucial, as timing the onset of human movement was heavily dependent on the statistical framework adopted (Blackwell and Buck 2003). Ironically, embracing the fundamental uncertainties associated with these processes, however, means that we often have to accept the limitations of the science, and at the moment, even using the best available statistical methods, the exact relationship between late Quaternary climate change and human adaptation is not clear (Blockley et al. 2006). Resolving such questions requires integrating ${ }^{14} \mathrm{C}$ information with evidence from other tools such as tephra, and here a Bayesian approach to age modeling will be ideal for such integration.

Bayesian calibration methods have now also been applied to the paleoclimate archives themselves. The majority of late Quaternary paleoclimate records are ${ }^{14} \mathrm{C}$-based and have dates that are stratigraphically ordered. This is ideal territory for Bayesian modeling and initial analyses showed that coherent age models are possible (Blockley et al. 2004). Since this initial work, a new generation of Bayesian depositional models have been developed. These explicitly incorporate the depositional information, such as the relative depth of individual dates and likely sediment deposition scenarios (Blaauw and Christen 2005; Bronk Ramsey 2008; Parnell et al. 2008). Recent test of some of these models against simulated data suggest that they are useful tools for depositional modeling (Blockley et al. 2007) and Bayesian methods should increasingly be useful for a variety of age modeling scenarios within Quaternary science.

The rise in the use of Bayesian tools actually encapsulates the developments in ${ }^{14} \mathrm{C}$ from the user perspective. The ability to incorporate information and expertise from the user end into devising a most likely final calibrated output is the power of the Bayesian approach, but this requires the user to be even more aware of and engaged in the details of ${ }^{14} \mathrm{C}$ science. We are now working in a time where the ${ }^{14} \mathrm{C}$ user has an embarrassment of riches - complex pretreatment strategies for different types of samples, long-term calibration data, and a variety of complementary dating methods, all of which can be integrated using Bayesian methods. The ${ }^{14} \mathrm{C}$ user is fortunate indeed to have such powerful tools, but must remember that these tools require due rigor in sample selection, model building, and final interpretation.

\section{REFERENCES}

Bayliss A, Whittle A, Wysocki M. 2007. Talking about my generation: the date of the West Kennet long barrow. Cambridge Archaeological Journal 17(Supplement S1):85-101.

Blaauw M, Christen JA. 2005. Radiocarbon peat chronologies and environmental change. Applied Statistics
54(4):805-16.

Blackwell PG, Buck CE. 2003. The Late Glacial human reoccupation of north-western Europe: new approaches to space-time modelling. Antiquity 77(296): 232-40.

Blockley SPE, Lowe JJ, Walker MJC, Asioli A, Trincardi 
F, Coope GR, Donahue RE. 2004. Bayesian analysis of radiocarbon chronologies: examples from the European Late-glacial. Journal of Quaternary Science 19(2):159-75.

Blockley SPE, Blockley SM, Donahue RE, Lane CS, Lowe JJ, Pollard AM. 2006. The chronology of abrupt climate change and Late Upper Palaeolithic human adaptation in Europe. Journal of Quaternary Science 21(5):575-84

Blockley SPE, Blaauw M, Bronk Ramsey C, van der Plicht J. 2007. Building and testing age models for radiocarbon dates in Lateglacial and Holocene sediments. Quaternary Science Reviews 26(15-16):1915-26.

Bronk Ramsey C. 2001. Development of the radiocarbon calibration program. Radiocarbon 43(2A):355-63.

Bronk Ramsey C. 2008. Deposition models for chronological records. Quaternary Science Reviews 27(1-2): 42-60.

Buck CE, Kenworthy JB, Litton CD, Smith AFM. 1991. Combining archaeological and radiocarbon information: a Bayesian approach to calibration. Antiquity 65(249):808-21.

Buck CE, Christen JA, James GN. 1999. BCal: an on-line Bayesian radiocarbon calibration tool. Internet $\mathrm{Ar}$ chaeology 7: http://intarch.ac.uk/journal/issue7/ buck_index.html.

Chiu T-C, Fairbanks RG, Mortlock RA, Bloom AL. 2005. Extending the radiocarbon calibration beyond 26,000 years before present using fossil corals. Quaternary Science Reviews 24(16-17):1797-808.

Danzeglocke U, Jöris O, Weninger B. 2007. CalPal online [WWW software]. http://www.calpal-online.de/.

De Vivo B, Rolandi G, Gans PB, Calvert A, Bohrson WA Spera FJ, Belkin HE. 2001. New constraints on the pyroclastic eruptive history of the Campanian volcanic Plain (Italy). Mineralogy and Petrology 73(1-3):4765

Fairbanks RG, Mortlock RA, Chiu T-C, Cao L, Kaplan A, Guilderson TP, Fairbanks TW, Bloom AL, Grootes PM, Nadeau M-J. 2005. Radiocarbon calibration curve spanning 0 to 50,000 years $\mathrm{BP}$ based on paired ${ }^{230} \mathrm{Th} /{ }^{234} \mathrm{U} /{ }^{238} \mathrm{U}$ and ${ }^{14} \mathrm{C}$ dates on pristine corals. Quaternary Science Reviews 24(16-17):1781-96.

Finlayson C, Fa DA, Jiménez Espejo F, Carrión JS, Finlayson G, Giles Pacheco F, Rodríguez Vidal J, Stringer C, Martínez Ruiz F. 2008. Gorham's Cave, Gibraltar-the persistence of a Neanderthal population. Quaternary International 181(1):64-71.

Higham T, Bronk Ramsey C, Karavanić I, Smith FH, Trinkaus E. 2006a. Revised direct radiocarbon dating of the Vindija $\mathrm{G}_{1}$ Upper Paleolithic Neandertals. Proceedings of the National Academy of Sciences of the USA 103(3):553-7.

Higham TFG, Jacobi RM, Bronk Ramsey C. 2006 b.
AMS radiocarbon dating of ancient bone using ultrafiltration. Radiocarbon 48(2):179-95.

Housley RA, Glamble CS, Street M, Pettitt P. 1997. Radiocarbon evidence for the Lateglacial human recolonization of northern Europe. Proceedings of the Prehistoric Society 63:25-54.

Hughen K, Southon J, Lehman S, Bertrand C, Turnbull J. 2006. Marine-derived ${ }^{14} \mathrm{C}$ calibration and activity record for the past 50,000 years updated from the Cariaco Basin. Quaternary Science Reviews 25(23-24): 3216-27.

Klein J, Lerman JC, Damon PE, Ralph EK. 1982. Calibration of radiocarbon dates: tables based on consensus data of the Workshop on Calibrating the Radiocarbon Time Scale. Radiocarbon 24(2):103-50.

Lowe JJ, Hoek WZ, INTIMATE group. 2001. Inter-regional correlation of palaeoclimatic records for the Last Glacial-Interglacial transition: a protocol for improved precision recommended by the INTIMATE project group. Quaternary Science Reviews 20(11): 1175-87.

Parnell AC, Haslett J, Allen JRM, Buck CE, Huntley B. 2008. A flexible approach to assessing synchroneity of past events using Bayesian reconstructions of sedimentation history. Quaternary Science Reviews 27(19-20):1872-85.

Pyle DM, Ricketts GD, Margari V, van Andel TH, Sinitsyn AA, Praslov ND, Nicolai D, Lisitsyn S. 2006. Wide dispersal and deposition of distal tephra during the Pleistocene 'Campanian Ignimbrite/Y5' eruption, Italy. Quaternary Science Reviews 25(21-22):271328.

Reimer PJ, Baillie MGL, Bard E, Bayliss A, Beck JW, Bertrand CJH, Blackwell PG, Buck CE, Burr GS, Cutler KB, Damon PE, Edwards RL, Fairbanks RG, Friedrich M, Guilderson TP, Hogg AG, Hughen KA, Kromer B, McCormac G, Manning S, Bronk Ramsey C, Reimer RW, Remmele S, Southon JR, Stuiver M, Talamo S, Taylor FW, van der Plicht J, Weyhenmeyer CE. 2004. IntCal04 terrestrial radiocarbon age calibration, 0-26 cal kyr BP. Radiocarbon 46(3):1029-58.

Stuiver M, Reimer PJ. 1986. A computer program for radiocarbon age calibration. Radiocarbon 28(2B): 1022-30.

Stuiver M, Reimer PJ. 1993. Extended ${ }^{14} \mathrm{C}$ data base and revised CALIB $3.0^{14} \mathrm{C}$ age calibration program. $R a$ diocarbon 35(1):215-30.

Stuiver M, Reimer PJ, Braziunas TF. 1998. High-precision radiocarbon age calibration for terrestrial and marine samples. Radiocarbon 40(3):1127-51.

van Andel TH. 1998. Middle and Upper Palaeolithic environments and the calibration of ${ }^{14} \mathrm{C}$ dates beyond 10,000 BP. Antiquity 72(275):26-33. 